Article

\title{
Irrigation Governance in Developing Countries: Current Problems and Solutions
}

\author{
Enrique Playán ${ }^{1, *}$, Juan Antonio Sagardoy ${ }^{2}$ and Rosendo Castillo ${ }^{3}$ \\ 1 Department of Soil and Water, Estación Experimental de Aula Dei, CSIC, Zaragoza 50059, Spain \\ 2 Independent Researcher, Rome 00124, Italy; sagardoy22@alice.it \\ 3 Consultora de Ingeniería Rural (CINGRAL), Santa Cruz 8, Zaragoza 50003, Spain; rcastillo@cingral.com \\ * Correspondence: enrique.playan@csic.es; Tel.: +34 976716087
}

Received: 14 June 2018; Accepted: 7 August 2018; Published: 23 August 2018

\begin{abstract}
The evolution of water governance and societal perception in large, public irrigation systems in developing countries has triggered successive waves of reforms since the 1980s. Among them are Participatory Irrigation Management, Irrigation Management Transfer, Public-Private Partnerships or Market Instruments. Reforms have generalized the implementation of Water Users Associations (WUAs) in continuous interaction with a public Irrigation Agency. This paper set out to review recurrent problems and reported solutions in the governance of irrigated areas in developing countries and to relate solutions to problems in a case study context. The combination of literature review and the experience of the authors permitted identification and characterization of eight problems and eight solutions. A semi-quantitative approach was designed to relate solutions to problems in case study WUAs. The approach is based on the definition of a generic problem-solution matrix and a WUA-specific problem vector. The solution vector indicates the adequacy of each solution to a case study WUA. It can be obtained by multiplying the problem vector with the problem-solution matrix. Application of this approach to seven case study WUAs demonstrated its potential. Local fine-tuning of the coefficients defining the problem-solution matrix seems required to draw conclusions effectively guiding decision-making.
\end{abstract}

Keywords: reform; Participatory Irrigation Management; Transfer; water users association

\section{Introduction}

World irrigation development accelerated in the twentieth century, following intense progress in civil engineering machinery and the push of governments and international development agencies. Many developing countries—often former colonies—changed their view on irrigation: from support to colonial agriculture to a national policy for employment and poverty eradication [1]. Between 1970 and 1990, the world area equipped for irrigation increased from 184 to $258 \mathrm{M}$ ha. Irrigation development continued, and by 1992 the area equipped for irrigation reached $324 \mathrm{M}$ ha [2]. Today the typical irrigation project in the world is located in Asia (70\%), draws from surface water resources $(62 \%)$, uses surface irrigation (86\%), attains a cropping intensity of 130\%, and grows cereals (61\%) [3].

Most of these irrigation projects were developed by governmental Irrigation Agencies, which were in charge of construction and delivering irrigation water. Farmers were rarely consulted during the phases of irrigation design and maintenance. By the 1980s, the performance of these new irrigation projects was dissatisfactory [4]. State-owned projects showed financial problems related to the low irrigation fees and to the difficulties in collecting them [5]. Low operation and management funding led to unreliable water delivery [6], which in turn precluded fee collection. Vermillion and Sagardoy [5] identified the lack of managerial accountability of governmental Irrigation Agencies as a critical issue. Deferred maintenance required cyclical rehabilitation interventions, giving birth to the well-known 
"reform-neglect-rebuild" cycle [1]. These perceptions led to the development and application of several reform procedures.

By the 1980s, irrigation organizations started seeking new irrigation management models. Vermillion and Sagardoy [5] reported that Irrigation Management Transfer (IMT) processes were implemented to involve water users in the governance of irrigated areas. These authors defined IMT as "the relocation of responsibility and authority for irrigation management from government agencies to non-governmental organizations". Garcés-Restrepo et al. [7] reviewed the motivations leading to IMT processes, and singled out some relevant factors: reduction of costs for the public sector, improvement of irrigation profitability, recovery of irrigation fees, efficiency and equitability of water allocation, infrastructure maintenance and settlement of disputes. During IMT processes, Water Users Associations (WUAs) were identified as a key elements for the new management models, although other organizations (such as cooperatives or municipalities) have adopted responsibilities in irrigation operation and management [4]. By 2007, more than 57 countries had embarked on some type of irrigation sector reform based on IMT [7].

Participatory Irrigation Management (PIM) was introduced as an attitudinal change, often accompanying the reforms introduced by IMT. According to Poddar et al. [6], PIM refers to users' involvement in all aspects of irrigation management, and consequently is a subset of the broader concept of IMT. Kloezen et al. [8] analyzed the successful results of IMT at the Alto Río Lerma irrigation district in Mexico, and identified the following key traits: a strong organizational base, cooperation between the public Irrigation Agency and the users, training, and political commitment.

By the end of the 20th century, water markets were promoted as a tool to improve irrigation governance [9]. Water markets make the opportunity cost of water use explicit, and therefore feed economic efficiency. According to Meinzen-Dick [10], the implementation of water markets requires physical infrastructure to mobilize water among users, effective, specific government organizations, and effective user groups. These requirements were met in Chile, where markets were developed in the 1990s.

A decade later, Public-Private Partnerships (PPP) were advocated by Prefol et al. [11] as a logical sequence of the preceding reform efforts. According to these authors, PPP can apply to investment, regulation, operation and management, and agricultural production. PPP can be formalized as public contracts or as public service delegations. Trier [12] reviewed PPP experiences in developing countries. According to this author, private financial contributions can be appropriate for modern systems with commercial farmers. In the context of subsistence agriculture, management contracts can be appropriate.

In the last forty years, countries and international developing agencies have promoted different waves of reforms, counting on a variety of funding arrangements. In general, reforms have focused more on operation and management than on construction and rehabilitation [1]. Reforms have followed the four models discussed in the preceding paragraphs (IMT, PIM, water markets and PPP). The combination of PIM/IMT has so far been the most applied model by far. Meinzen-Dick [10] reviewed reform organizational models, which she qualified as alleged "panaceas" to denote that each of them had been proposed to solve all existing governance problems. In her view, solutions are needed that "fit the local biophysical, social and economic conditions". This diagnose suggests that despite all the reported efforts, the problems found in the governance of irrigated areas have not been solved.

After decades of irrigation reform practice, several hot issues remain in irrigation governance: Garcés-Restrepo et al. [7] outlined the need for more efficient and equitable water delivery, and for an endogenous capacity to solve disputes. Kloezen et al. [8] reported on the complex issue of redeploying the large public staff in the Irrigation Agency following IMT. Yildirim and Çakmak [13] stated that for sustainable PIM, users need to invest in the construction of the irrigation systems. Teamsuwan and Satoh [14] recognized that it was easy to create and strengthen WUAs in Thailand, but anticipated that their sustainability would be problematic. Bhatt [15] reported on several farmers', 
organizational, systemic and operational issues preventing the success of PIM in India. Ul Hassan [16], analyzing IMT governance in Asia, reported shortcomings stemming from poor accountability and transparency in the legal and policy environment. Veldwisch and Mollinga [17] observed that the local IMT policy in Uzbekistan established WUAs under strong state tutelage. Analyzing IMT implementation in Indonesia, Suhardiman [18] concluded that the Irrigation Agency and international donors had common interests in implementing IMT using a business-as-usual approach. As a corollary of all these hot issues, after reviewing 230 case studies in the literature, Senanayake et al. [19] found it impossible to conclude about the success or failure of IMT processes, owing to the weaknesses of the methods used to infer impact and to problems inherent to the available information.

These findings call for a structured approach to the actual problems of irrigation governance in developing countries and to their solutions. MASSCOTTE [20] is a contribution to the problem-solution analysis, focusing on large canal systems and on a comprehensive approach to operation modernization. It is based on a Rapid Appraisal Process systematically covering all aspects of engineering, governance, maintenance, and operation.

While many developed countries have found a way to reduce the public burden of irrigation governance, ensuring adequate system maintenance and satisfaction of users' needs, most developing countries continue to be trapped in a cycle of successive reforms yielding moderate progress. Asthana [21] reported disenchantment with irrigation projects in developing countries, quoting reasons such as environmental issues, displacement, time and cost overruns, inequities and corruption. According to this author, projects are creating less irrigation potential than planned.

The objectives of this paper are to: (1) critically review the problems and reported solutions in the governance of irrigated areas in developing countries; and (2) relate solutions to problems in a case study context, contributing to the creation and utilization of value in irrigated areas. The paper draws from analyses and examples in the literature and from the experience of the authors.

\section{Irrigation Infrastructure: Models for Ownership and Management}

For this paper, an irrigation system can be divided in five elements:

- General-purpose, large water works (serving all types of water uses);

- Rural, large water works (delivering water to irrigated areas);

- Rural, small water works (delivering water to farms);

- The hydrant or the WUA canal turnout (separating the public or collective part from a farm); and

- The on-farm irrigation structures.

In this section, different models are discussed for the ownership and the management of these five elements (see Figure 1 for a chart and acronyms representing different models).

Regarding ownership, there are three basic models: (O1) public delivery networks with private farms; (O2) public, collective and private ownership; and (O3) collective and private ownership. Farmers' organizations (such as a WUA, a cooperative or a municipality) own the collective part of the system.

Regarding management, the situation is much more complex, with many variants. Most irrigated areas have started with a model based on a very strong public intervention (M1). IMT processes led to models M2 and M3, in which users' associations manage (and often own) rural water works and the delivery point to farms (the canal turnout or the hydrant). In the most advanced models, a users' organization in a developed area can manage private farmers' irrigation and large (even general-purpose) water infrastructure (M4 and M5).

Public management is performed by the Irrigation Agency (IA). This generic name corresponds to a variety of organizations in different countries and irrigated areas. IAs can take the form of Ministries, River Basin Authorities, Irrigation project authorities or even municipalities. These organizations operate in the name of the Government. If PPP schemes have been adopted, management can be performed by companies operating in the name of the Government. 
In this paper, problems and solutions are analyzed for irrigation systems having public and/or collective infrastructure. This is not the case, for instance, of most groundwater systems and of the systems composed of individual pumps along a riverbank.

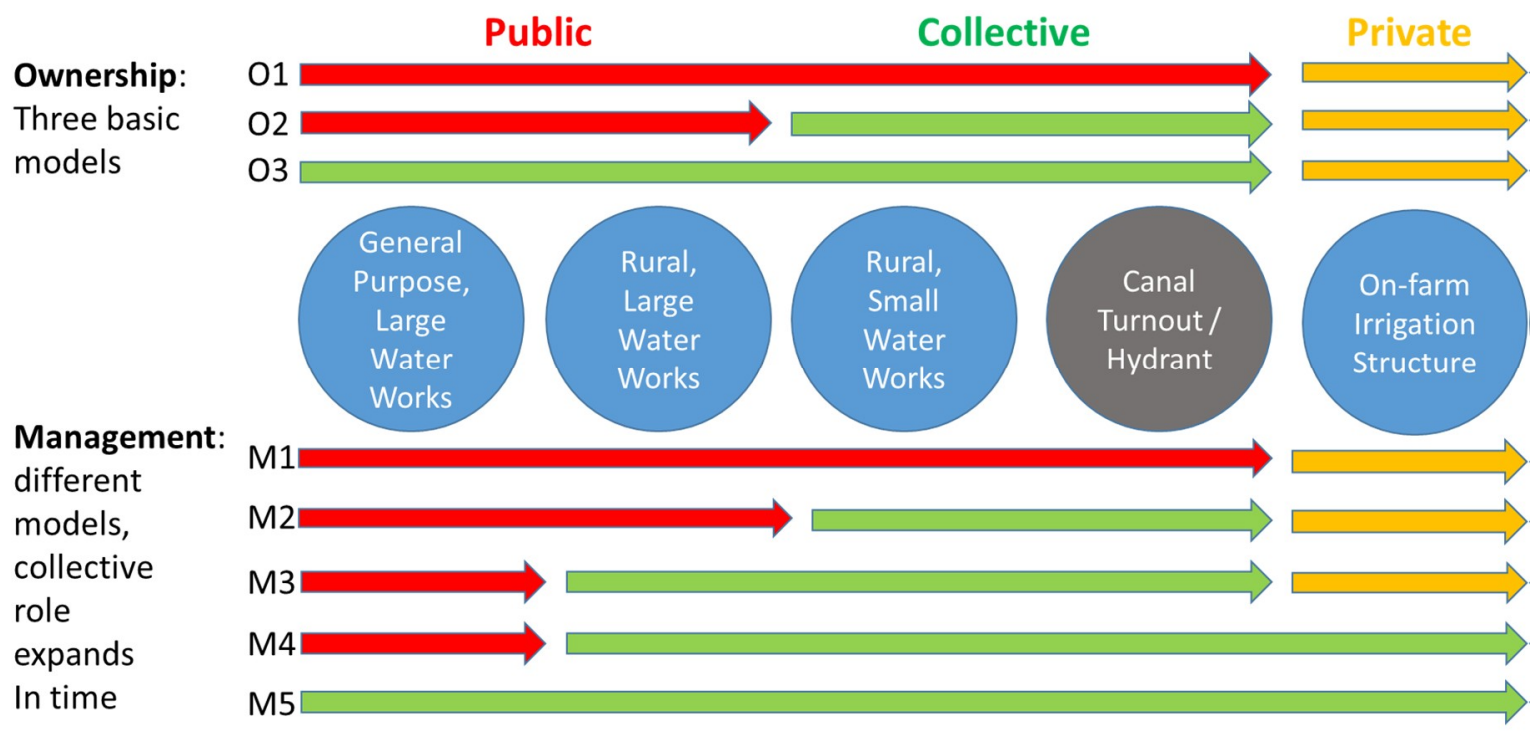

Figure 1. Models for ownership and management of irrigation infrastructure: combination of public, collective and private intervention.

\section{The Time Line of an Irrigation System}

Table 1 presents the idealized time line of the development of an irrigation system. The process has been divided in four phases: planning, implementation, consolidation, and maturity. In a development context, the duration of the first three phases has been estimated in 3-5 years, 2-4 years and a decade, respectively. The last phase, maturity, has an undetermined duration. For every phase, three focus areas have been considered: (1) technical; (2) legal and regulatory; and (3) socioeconomic. Technical issues have been attributed to the Government, the IA, the WUAs and the farmers. Thirty-two actions have been identified, leading to the successful completion of the irrigation system timeline.

The need for reform can appear at any point within the time line. However, reform needs are a common outcome of monitoring and evaluation. Market instruments and PPPs are often planned for and even introduced in the planning phase of the irrigation system. PIM/IMT can be introduced at the planning phase but will typically be implemented during the consolidation phase. This may be planned for (as in Table 1) or may arise with the need for reforms.

The consolidation phase is therefore a critical point in the time line. Problems may appear in this phase that compromise the maturity of the project and seriously threat its sustainability. In many projects worldwide, reform has been identified as a critical requirement to consolidate the irrigation system or to pass from the consolidation phase to the maturity phase. As previously discussed, the implementation of reforms does not necessarily lead to the consolidation or maturity of an irrigation system. 
Table 1. Idealized time line of an irrigation system, covering the phases of planning, implementation, consolidation, and maturity from the technical, legal and regulatory, and socioeconomic perspectives. A set of 25 actions has been identified and associated to phases and perspectives.

\begin{tabular}{|c|c|c|c|c|c|c|c|c|c|c|c|c|c|c|c|c|c|c|c|c|c|c|c|c|c|c|}
\hline \multirow{3}{*}{\begin{tabular}{|l} 
Phases of irrigation system development: \\
Focus areas: \\
Actions \\
\end{tabular}} & \multicolumn{6}{|c|}{ Planning } & \multicolumn{7}{|c|}{ Implementation } & \multicolumn{6}{|c|}{ Consolidation } & \multicolumn{7}{|c|}{ Maturity } \\
\hline & \multicolumn{4}{|c|}{ Technical } & \multirow{2}{*}{\multicolumn{2}{|c|}{ 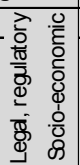 }} & \multirow{2}{*}{\multicolumn{2}{|c|}{ 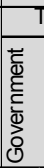 }} & \multicolumn{3}{|c|}{ chnical } & \multirow{2}{*}{ 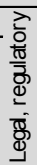 } & \multirow{2}{*}{ 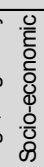 } & \multirow{2}{*}{ 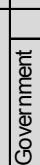 } & \multicolumn{3}{|c|}{ Technical } & \multirow{2}{*}{ 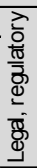 } & \multirow{2}{*}{ 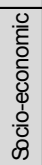 } & \multicolumn{5}{|c|}{ Technica } & \multirow{2}{*}{\multicolumn{2}{|c|}{ 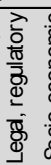 }} \\
\hline & 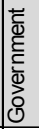 & $\begin{array}{l}\text { তे } \\
\frac{5}{8} \\
\end{array}$ & & 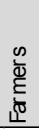 & & & & & ర্口 & & 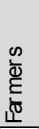 & & & & & 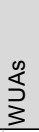 & $\sum_{\frac{\omega}{\omega}}^{\infty}$ & & & 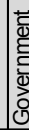 & & & & $\sum_{\overparen{\varpi}}^{\infty}$ & & \\
\hline 1. Structuring the project development team & $\mathrm{X}$ & & & & & & & & & & & & & & & & & & & & & & & & & \\
\hline $\begin{array}{l}\text { 2. Setting up a demonstration farm near the project area } \\
\text { experimenta fields, irrigation facilties and cooper ating } \\
\text { farmers }\end{array}$ & $\mathrm{x}$ & $X$ & & $x$ & & & & & & & & & & & & & & & & & & & & & & \\
\hline $\begin{array}{l}\text { 3. Visiting simila areas with the project team and future } \\
\text { WUA personnel }\end{array}$ & $x$ & $\mathrm{x}$ & $\mathrm{X}$ & & & & & & & & & & & & & & & & & & & & & & & \\
\hline $\begin{array}{l}\text { 4. Developing solutions adapted to different farming } \\
\text { models: subsistence, family, entrepreneurs and agribusiness }\end{array}$ & $x$ & $X$ & & & & & & & & & & & & & & & & & & & & & & & & \\
\hline 5. Defining the legal framework of the project & & & & & $\mathrm{x}$ & & & & & & & & & & & & & & & & & & & & & \\
\hline $\begin{array}{l}\text { 6. Avoiding over lapping organisms, defining governance } \\
\text { roles and responsibilities }\end{array}$ & & & & & $x$ & & & & & & & & & & & & & & & & & & & & & \\
\hline 7. Developing financial systems adapted to solutions above & $X$ & $X$ & & & & $\bar{X}$ & & & & & & & & & & & & & & & & & & & & \\
\hline $\begin{array}{l}\text { 8. Developing procedures for the procurement, } \\
\text { contracting and control of the construction works }\end{array}$ & & & & & $x$ & & & & & & & & & & & & & & & & & & & & & \\
\hline $\begin{array}{l}\text { 9. Building irrigation infr astructure counting on local } \\
\text { companies. Iniciating future WUA per sonnel in the use of } \\
\text { machinery }\end{array}$ & & & & & & & & & $X$ & & & & & & & & & & & & & & & & & \\
\hline $\begin{array}{l}\text { 10. Andyzing staple and agribusiness crops. Testing in real } \\
\text { farms procedures developed in the demonstration farm }\end{array}$ & & & & & & & & & $x \quad x$ & $x$ & $x$ & & & & & & & & & & & & & & & \\
\hline $\begin{array}{l}\text { 11. Providing technical support: from Government and/or } \\
\text { Agency to WUAs and farmers }\end{array}$ & & & & & & & $x$ & $x>$ & $\mathrm{X}$ & & & & & & & & & & & & & & & & & \\
\hline $\begin{array}{l}\text { 12. Developing geodatabases for plots, users, crops, } \\
\text { meteorology, infrastructures }\end{array}$ & & & & & & & & & $x$ & $\mathrm{X}$ & & & & & & & & & & & & & & & & \\
\hline $\begin{array}{l}\text { 13. Developing on-farm irrigation systems fit to the local } \\
\text { constraints and the farming models }\end{array}$ & & & & & & & $x$ & $x$ & $x$ & & $x$ & & & & & & & & & & & & & & & \\
\hline $\begin{array}{l}\text { 14. Initiating WUA personnel and farmers in IMT/PIM: a) } \\
\text { O\&M for canals, ditches and open drains; b) WUA } \\
\text { management and participation }\end{array}$ & & & & & & & & & $x \times$ & $\mathrm{X}$ & $x$ & $\mathrm{X}$ & & & & & & & & & & & & & & \\
\hline 15. WUA by-laws, porcedures for conflict resolution & & & & & & & & & & & & $X$ & & & & & & & & & & & & & & \\
\hline 16. Seeking actors' commitments on WUA O\&M & & & & & & & & $\bar{x})$ & $\bar{x} x$ & $\mathrm{X}$ & $\mathrm{X}$ & & & & & & & & & & & & & & & \\
\hline $\begin{array}{l}\text { 17. Fostering market orientation of farmers. Selection of } \\
\text { models (cooperatives, agribusiness...) }\end{array}$ & & & & & & & $x$ & $x$ & & & & & $\mathrm{x}$ & & & & & & $x$ & & & & & & & \\
\hline $\begin{array}{l}\text { 18. Considering gender issues in WUAs and farming } \\
\text { models: governance and participation }\end{array}$ & & & & & & & & & & & & & $x$ & & & & & & $x$ & & & & & & & \\
\hline $\begin{array}{l}\text { 19. Professionalizing WUAs: hiring technical staff, } \\
\text { controlling the water cycle and mastering O\&M }\end{array}$ & & & & & & & & & & & & & & & & $x$ & & & & & & & & & & \\
\hline 20. Setting up Irrigation Service Fees covering O\&M cost & & & & & & & & & & & & & & & & $X$ & $x$ & & & & & & & & & \\
\hline $\begin{array}{l}\text { 21. Materializing PIM: electing of WUA representatives, } \\
\text { consolidating WUA authority on the part of the users }\end{array}$ & & & & & & & & & & & & & & & $x$ & $\mathrm{x}$ & $\mathrm{x}$ & & & & & & & & & \\
\hline 22. Materializing IMT/PIN: allocating responsibilities & & & & & & & & & & & & & & & $\mathrm{X}$ & $\mathrm{X}$ & $\mathrm{X}$ & & & & & & & & & \\
\hline 23. Technifying cooper atives to compete in the market & & & & & & & & & & & & & & & & & & & $\mathrm{X}$ & & & & & & & \\
\hline $\begin{array}{l}\text { 24. Fostering interaction between WUAs and } \\
\text { Cooperatives: Fertilizers, plant protection, Irrigation } \\
\text { techniques for market penetration }\end{array}$ & & & & & & & & & & & & & & & & $x$ & $x$ & & $x$ & & & & & & & \\
\hline $\begin{array}{l}\text { 25. Managing for all types of water users: hydropower, } \\
\text { ir rigation and cities }\end{array}$ & & & & & & & & & & & & & & & $x$ & $x$ & $x$ & & $x$ & & & & & & & \\
\hline 26. Continuous monitoring and evaluation activities & & & & & & & & & & & & & & $\mathrm{X}$ & $\mathrm{X}$ & $\mathrm{X}$ & $\mathrm{X}$ & $\mathrm{X}$ & $\mathrm{X}$ & $x$ & & $\mathrm{X}$ & $\mathrm{X}$ & $\mathrm{X}$ & $\mathrm{X}$ & $\mathrm{X}$ \\
\hline $\begin{array}{l}\text { 27. Seeking WUA independence from the Government } \\
\text { and the Agency }\end{array}$ & & & & & & & & & & & & & & & & & & & & & & & $\mathrm{X}$ & & & $x$ \\
\hline $\begin{array}{l}\text { 28. Considering modernization actions in WUA } \\
\text { infrastructure }\end{array}$ & & & & & & & & & & & & & & & & & & & & & & $\mathrm{X}$ & $x$ & & & $\mathrm{x}$ \\
\hline 29. Providing legal security to users and investors & & & & & & & & & & & & & & & & & & & & & & & & & $\mathrm{X}$ & \\
\hline 30. Gaining access to new technologies & & & & & & & & & & & & & & & $\mathrm{X}$ & $\mathrm{X}$ & $x$ & & & & & & & & & \\
\hline $\begin{array}{l}\text { 31. Controlling irrigation return flows and non-point } \\
\text { source pollution }\end{array}$ & & & & & & & & & & & & & & & $x$ & $\mathrm{x}$ & $\mathrm{x}$ & & & & & & & & & \\
\hline $\begin{array}{l}\text { 32. Integrating WUAs in national and international scene. } \\
\text { Sharing experiences, improving self-steem }\end{array}$ & & & & & & & & & & & & & & & & & & & & & & & $x$ & & & \\
\hline
\end{tabular}




\section{Current Problems}

In the following sections, problems precluding the success of the abovementioned reform models are presented. The list of problems is loosely based on the analysis performed by Garcés-Restrepo et al. [7] in their Table 14. These authors presented an analysis of world implementation of IMT, identifying and ranking a set of 19 problems and issues. Ranking was performed according to the global relevance of each item, although the regional relevance of each problem was also provided. In this paper, discussion has been extended to all reform models (not just IMT), the number of problems has been reduced, and additional sources of evidence have been considered. Table 2 presents the eight current problems, and their correspondence to those identified by Garcés-Restrepo et al. [7]. Instead of following a relevance ranking, our list of problems follows a functional approach: resistance to reform, reform framework, construction project, infrastructure, organization, capacities, training, and cost recovery. Seven of the eight problems correspond to some of the items in the list of Garcés-Restrepo et al. [7]. The poor conception of the irrigation system project does not correspond to any of the items in that list.

For each problem below, the first paragraph contains a description based on scientific evidence. The second paragraph derives from the experience of the authors in irrigation research, engineering, and international consulting.

\subsection{Agency and Government Officials Resist Reform}

This is the most frequently identified problem, according to Garcés-Restrepo et al. [7]. Agency and government resistance to reform ranked first in the list of problems in all regions of the world. Suhardiman and Giordano [1] realized that policy intervention in government-managed irrigation systems had not significantly improved performance, and set out to analyze the nature of "irrigation bureaucracies" and their effect on the outcome of reform. According to these authors, bureaucracies are actors rather than instruments in reforms, and have their own missions and interests: the "hydraulic mission". In application of this mission, the Agency and its officials see their budget and power legitimized by the role of irrigation infrastructure and water security in national economic development. Suhardiman and Giordano [1] stated that irrigation bureaucracies created the "reform-neglect-rebuild" cycle to sustain their autonomy, attracting a continuous flow of development funds. Resistance reduces the scope of reform to cost recovery, recentralizes rather than decentralizes, and can ultimately neutralize reforms.

We have identified three additional reasons why Irrigation Agencies resist irrigation system reform. The first one is that political support to the program is insufficient. Agencies will generally not be enthusiastic about reform if they fear that the continuity or depth of the reform is not granted. The second reason is that reforms such as PIM/IMT require new expertise that Agency officials most likely will not have. The third reason is that reform may be designed to downscale the role, the size, and the responsibilities of the agency. This may be a threat to the employment and the careers of Agency officials. 
Table 2. Correspondence between the ranked list of problems and issues in implementing IMT (Table 14 in Garcés-Restrepo et al., 2007 [7]), and the list of current problems in irrigation governance discussed in this paper.

\begin{tabular}{|c|c|c|c|c|c|c|c|c|}
\hline \multirow[b]{2}{*}{$\begin{array}{l}\text { Problems and Issues in Implementing IMT, } \\
\text { Table } 14 \text { in Garcés-Restrepo et al. (2007) [7] }\end{array}$} & \multicolumn{8}{|c|}{ Current Problems in Irrigation Governance } \\
\hline & $\begin{array}{c}\text { Agency and } \\
\text { Government Officials } \\
\text { Resist Reform }\end{array}$ & $\begin{array}{l}\text { Farmers } \\
\text { Resist } \\
\text { Reform }\end{array}$ & $\begin{array}{l}\text { Weak legal and } \\
\text { Financial Reform } \\
\text { Framework }\end{array}$ & $\begin{array}{c}\text { Poor Conception } \\
\text { of the Irrigation } \\
\text { System Project }\end{array}$ & $\begin{array}{c}\text { Irrigation } \\
\text { Systems } \\
\text { Deteriorated }\end{array}$ & $\begin{array}{l}\text { Unsuitable WUA } \\
\text { Organization } \\
\text { Structure }\end{array}$ & $\begin{array}{c}\text { Weak } \\
\text { Capacities } \\
\text { of WUAs }\end{array}$ & $\begin{array}{l}\text { Inadequate } \\
\text { WUA Cost } \\
\text { Recovery }\end{array}$ \\
\hline $\begin{array}{l}\text { Resistance to IMT by agency } \\
\text { Inadequate training of WUA }\end{array}$ & $x$ & & & & & & & \\
\hline Difficult for govt. to finance IMT & & & $\mathrm{x}$ & & & & & \\
\hline Irrigation systems heavily deteriorated & & & & & $\mathrm{x}$ & & & \\
\hline $\begin{array}{l}\text { Weak capacity to train WUA } \\
\text { Weak legal framework for IMT }\end{array}$ & & & $x$ & & & $x$ & & \\
\hline Inadequate farmer payment for O\&M & & & & & & & & $\mathrm{x}$ \\
\hline $\begin{array}{l}\text { Weak techn. and mngt. capacity of WUA } \\
\text { Inadeguate training for govt staff }\end{array}$ & & & & & & & $\mathrm{x}$ & \\
\hline $\begin{array}{l}\text { Inadequate training for govt. staft } \\
\text { Agency reform and staff disposition }\end{array}$ & $\mathrm{x}$ & & & & & & & \\
\hline $\begin{array}{c}\text { Farmers resist IMT } \\
\text { No clear/single IMT policy or Programme }\end{array}$ & & $\mathrm{x}$ & $\mathrm{x}$ & & & & & \\
\hline Resistance to IMT by local government & $\mathrm{x}$ & & & & & & & \\
\hline Democratic elect. of WUA officers difficult & & & & & & $\mathrm{x}$ & & \\
\hline Conflicts between farmers/villages & & $\mathrm{x}$ & & & & $\mathrm{x}$ & & \\
\hline $\begin{array}{l}\text { Politicians resist IMI } \\
\text { Inadequate support services }\end{array}$ & & & & & & & $\mathrm{x}$ & \\
\hline WUA cannot apply sanctions & & & & & & $\mathrm{x}$ & & \\
\hline Farmers lack access to credit & & & & & & & & $\mathrm{x}$ \\
\hline
\end{tabular}




\subsection{Farmers Resist Reform}

Bhatt [15] presented a rather negative profile of Indian farmers when confronting PIM. In her perspective, farmers were suspicious, reluctant to adopt responsibilities and had little knowledge of technical issues. Farmers did not trust that the WUAs created under PIM reforms would adequately satisfy their demand for irrigation water. Meinzen-Dick et al. [22] analyzed the factors affecting farmers' collective action in the management of water resources in India. Several the key factors were intangible in nature, such as the leadership and social capital. Hu et al. [23] reported that the creation of WUAs in China in the context of PIM reforms did not necessarily lead to increased farmers' participation. Surveys indicated that farmers did not understand the nature, function, and participatory approach of the WUAs. Yami [24] claimed that the little attention paid to community inputs when building WUAs in Ethiopia seriously affected their acceptability and effectiveness. Aydogdu et al. [25] analyzed farmers' satisfaction with WUAs in the Turkish GAP project. These authors reported on the general opinion that WUAs failed to perform their duties completely. According to Garcés-Restrepo et al. [7], Farmers' resistance to IMT was in the middle of the ranked list of problems. Another item on the list, the conflicts between farmers and villages, can contribute to the resistance of farmers to IMT.

It is somehow natural that farmers resist: reform always represents a profound change in the way water is distributed and managed. More importantly, reforms such as PIM/IMT represent a sociological change that intends to involve users in water management decision-making in countries or local situations where such tradition does not exit. It is also logical that farmers do not trust a new management system that is generally imposed by the same IA that failed in creating an atmosphere of mutual confidence. Knowing that this is a potential problem, the conclusion may be advanced that not enough was done in many cases to disseminate the reform messages. Most of the references in the previous paragraph refer to the initial phase of WUA establishment. Not enough energy was used to let farmers understand the nature of their new responsibilities. On the other hand, expectations of farmers' participation are often placed too high. This is particularly true in large irrigation systems, where day-to-day operations are carried out by technical staff. In such systems, as long as water services are satisfactory, farmers limit their participation to raise complaints and to participate in formal institutional meetings.

\subsection{Weak Legal and Financial Reform Framework}

This heading directly relates to three elements in the list of problems by Garcés-Restrepo et al. [7] (Table 2): the difficulty for governments to finance IMT, the weak legal framework for IMT, and the fact that there is no clear/single IMT policy or program. The first step to a sound legal reform framework is the explicit registration of water rights. When discussing the IMT reform in Mexico, Kloezen et al. [8] pointed out that the new Water Act established in 1992 did not provide water rights to individual users, and did not establish allocation rules in the case of water scarcity. However, the Act permitted the signing of tradable water concession agreements and the utilization of districts' infrastructure by private parties. Analyzing water management in India, Poddar et al. [6] stated that since water rights were not attributed to individuals, reforms based on water markets could not be introduced. However, as recognized by these authors, explicit, nominal water rights are needed for farmers to invest and maintain irrigation infrastructure. Regarding the institutional framework, Meinzen-Dick [10] observed that donors and policy makers would like to apply similar reforms in all contexts, applying the panacea paradigm. To overcome the failures resulting from this ill approach, she advocated for a polycentric governance model in which state, collective, and market institutions played a role.

During IMT processes, WUAs have often been established without a proper legislation that recognizes them as legal entities. In Jordan, for instance, the lack of specific legislation for WUAs led to cooperatives being used for collective water management. This induced specific problems in water management. In other cases, the legal framework establishes that WUAs are associations of private nature, which is contradictory with an association that manages a public good: water. One of the most successful PIM/IMT programs has been carried in Turkey. From the legal point of view, this program 
was based on an internal regulation of the General Directorate of State Hydraulic Works (DSI) that allowed the institution to transfer the management of irrigation systems to water users' organizations when appropriate. Only recently, a law has been published regulating the whole process.

\subsection{Poor Conception of the Construction/Rehabilitation Projects of the Irrigation System}

Critical design deficiencies limit irrigation system performance and cannot be exclusively solved by governance measures. Examples of design shortcomings include selection of incorrect solutions, errors in the sizing of system structures and use of inadequate technologies. Orstrom [26] pointed out frequent engineering misconceptions in irrigation projects. The benefit-cost analysis, the area to be irrigated and the agricultural yields were often overestimated. On the contrary, the recurrent costs of operation and maintenance were systematically underestimated. This perception is in agreement with the profile of the irrigation bureaucracies described by Suhardiman and Giordano [1]. While reviewing the effectiveness of PIM reforms in Cambodia, Asthana [21] stated that competition to get a project approved can lead to exaggerate the expected benefits and to understate the project costs. Orstrom [26] and Vos [27] stated that government-managed projects were often too large to be efficient. These large projects focused on the engineering works, and often left water distribution, maintenance, and farmers' organization unattended. In the best of cases, as reported by Orstrom [26], government officials would only describe the main structure of the farmers' organization. This author described the process of institution crafting, that she anticipated would become more intense than engineering works in the decades to come. This approach was later on adopted by the World Bank in their Comprehensive Development Framework [28]. Ortstrom [26] concluded that farmers must be involved in the physical and financial design of the irrigation systems, and that they must have decision-making capacity. These statements were adopted by Vermillion and Sagardoy [5], when declaring that WUAs must be in the driver's seat of IMT reforms. This enables users to identify and prioritize options, and to make financial decisions. This participative approach to infrastructure development was widely accepted in the 20th century $[4,13]$.

The ex-ante cost-benefit assessment of public projects continues to be optimistic in all types of projects (not just in irrigation) and in all regions of the world. Large and complex irrigation systems have proven successful in developed regions or for commercial irrigated agriculture. However, small, community-targeted projects are currently being designed for developing regions or in contexts of subsistence farming. In such environments, users' institutions develop with the project (actions 3, 9, 11, 14 in Table 1), and often do not have enough strength to guide project decisions, particularly at the time of the initial construction. Rehabilitation projects making part of reform policies often count on more organized users. Participation in project physical and financial design will greatly facilitate users' implication in O\&M and cost recovery.

\subsection{Irrigation Systems Deteriorated}

This item was considered relevant in the list by Garcés-Restrepo et al. [7] (Table 2). Vermillion and Sagardoy [5] described the processes of rapid irrigation system deterioration. The area actually irrigated decreased in time, as water distribution became undependable. Water misuse induced waterlogging and salinity problems. System deterioration widened the gap between actual and potential irrigation performance. This gap is one of the factors triggering the reform of government-managed irrigation systems [22]. According to Vermillion and Sagardoy, an assessment of the performance gaps is needed to evaluate the actions required at the irrigation system, taking into account two options: enhancement or reform [5]. These authors stated that a history of enhancement actions with a continuously widening gap is a clear sign of the need for reform. They also warned that political feasibility (enhancement) may override the real needs of the system (reform). Suhardiman and Giordano [1] stated that the vicious cycle of poor financial and institutional arrangements, deferred maintenance, infrastructure deterioration and poor performance explains the typical low performance of government-managed irrigation systems. 
Irrigation system deterioration remains a fundamental problem and is one of the major reasons for implementing PIM/IMT programs. Insufficient government budget to finance rehabilitation/modernization projects and the difficulties to borrow from national or international banks may lead to the transfer of degraded irrigation systems. This creates a challenge for the new WUAs, which may confront serious operating problems. If irrigation cannot proceed normally, farmers will have limited financial capacity to contribute to the repayment of investment costs, and therefore the full cost of the rehabilitation/modernization will have to be covered by the Government. In some cases, rehabilitation projects have been implemented without establishing WUAs. These are examples of irrigation system enhancement, in which the need for successive projects will most likely arise again in the following years.

\subsection{Unsuitable WUA Organization Structure}

Vermillion and Sagardoy [5] recognized that one of the key drivers for IMT was fostering managerial accountability in the irrigation sector. According to these authors, these user-driven organizations needed to incorporate incentives, sanctions, and transparency. After forty years of practice, it can be stated that PIM/IMT has improved collective water management and empowered users. In general, the process counted on a transition period characterized by Agency-WUA cooperation [8]. Veldwisch and Mollinga [17] reported that government control of Uzbek WUAs continued to be strong even after the transition period, with WUAs implementing state control over water distribution and agricultural production. According to these authors, WUAs were held responsible for state production targets, and WUA leaders were appointed by the Government. In fact, Garcés-Restrepo et al. [7] included the difficulty in holding democratic elections for WUA leaders in their list of IMT problems. Despite these difficulties, PIM/IMT has resulted in significant independence of WUAs from their governments after long development periods [15]. Several authors have analyzed WUA organizational problems hindering PIM implementation in different areas of the world [15,23-25,29-31]. These authors identified the following additional issues: (1) interference between WUAs, village governments and agricultural cooperatives; (2) unclear duties and authority of WUA managers; (3) strong government policies, hindering WUA functionality; (4) marginalization of rural women in WUA decision-making; and 4) lack of supportive policy and legal WUA regulations.

The case of Turkey demonstrates that several types of organizations can be used in the same PIM/IMT program if each type is applied taking into consideration the local conditions and the possibilities to provide adequate supporting services to farmers. Often the problem is that serious limitations are imposed to WUAs. In some cases, not all farmers benefiting from the irrigation system are WUA members because association is not mandatory. In other cases, key management functions are still carried by government agencies. This can imply the operation of key irrigation structures (pumping stations, canals, dams, etc.) essential for efficient WUA management. As a result, WUAs have limited responsibility in managing the irrigation system. In some irrigation systems, WUAs are not authorized to act as contractors for certain rehabilitation works. Finally, WUAs may lack a section in charge of operation and maintenance or established procedures for internal conflict solving.

\subsection{Weak Capacities of WUAs (Technical, Managerial)}

Reforms analyzed in this paper have permitted more progress in developed than in developing environments $[6,19]$. While this can be attributed to several economic, societal and policy factors, WUA capacities stem as a major cause. In fact, Garcés and Restrepo [7] listed several WUA training requirements following IMT. The early success of the Mexican IMT program has been linked to efforts in increasing the capacities of the emerging WUAs [8]. Part of the problems related to WUA capacities derive from the continuity of Agency personnel in the newly created WUAs and from the absence of WUA staff selection procedures [7,8]. Hamada and Samad [4] identified some of the unfair factors that can appear in PIM areas when WUA capacities are far from optimum: dominance of upstream and large-scale farmers, low participation of female farmers, failure to collect fees, and 
lack of financial transparency. Bhatt [15] compiled operational problems for PIM implementation in India, and underlined the importance of financial provisions as drivers for capacities, and lack of knowledge about tasks such as record-keeping and accounting. Omid et al. [32] reported that Iranian WUA success relied on WUA capacities for administrative procedures, operation of irrigation facilities and water fee collection.

At the root of these problems is the absence of professionals to carry out the daily WUA responsibilities. This is often caused by the insufficiency of the collected irrigation service fees (ISF) to hire external personnel. Ultimately, this depends on the size and ambition of the WUAs. In some areas of the world, WUAs are large and can mobilize funds and staff to maximize performance; in other areas, WUAs are very small and focus on maintaining watercourses. Since small WUAs cannot afford to hire technical staff, high levels of performance are rarely achievable in small WUAs, increasing the risk of system deterioration. Limitations in WUA capacities difficult the implementation of monitoring and evaluation procedures. Most of these problems could be solved with the training of WUA personnel. However, traditional (classroom) training has proven ineffective in many instances. On-the-job training in communities of practice stands chances of being effective in this environment.

\subsection{Inadequate WUA Cost Recovery}

The collection of ISF was identified as a cause for irrigation reform since the first applications of IMT in Mexico [8]. Several reasons were provided to explain weak fee collection: distance to the payment offices, need to wait in line, bribing government officials and ditch tenders, and the lack of consequences. In fact, ISF recovery was one of the major strengths of the Mexican IMT: collection rates approached $100 \%$, the cost to farmers did not increase, and WUA self-sufficiency increased from 50 to $120 \%$. Even after PIM/IMT, many WUAs remain trapped in a vicious circle of "insufficient maintenance-downgrading infrastructure-poor performance-low-cost recovery" [11]. Cases of this vicious circle have been documented in Tunisia and Pakistan [31,33]. WUAs have been reported to approve deficit budgets to match farmers' willingness to pay. Governmental subsidies have been documented after IMT, in cash or in kind [34]. In many countries, WUAs are not allowed by the Government to apply sanctions to farmers not paying their bills. In some cases, WUAs are exposed to high inflation rates or to unexpected repairs or investments, and they find it difficult to face the related expenses [8]. In other cases, problems are created within the WUA, with corruption, fraud and bribing [5]. According to Hamada and Samad [4], one of the PIM objectives was to stimulate a more productive and self-reliant irrigated agriculture, which could support reliable, professional water management. Ounvichit et al. [35], when analyzing an irrigation system in southern Thailand, reported that explicit economic returns from farming would increase all types of farmers' participation in WUAs. Unfortunately, donors and governments often have not focused on economic sustainability when selecting project proposals. In this sense, the criteria for investment in irrigation systems published by Orstrom [26] continue to be relevant.

In our view, this is the most serious problem that WUAs face, since it is not possible to operate permanently under economic deficit. In many cases, it remains unclear if farmers cannot pay or if they do not want to pay. The subsidies applied to WUAs in many countries are a source of controversy. In general, subsidies distort the market and create perverse economic effects. However, in some cases, subsidies can be a solution rather than a problem. Subsidies should be seen in the context of the public interest in the irrigation project and its infrastructures. In fact, in some countries and development contexts, subsidies applied to part of the operation and management costs can be a cost-effective alternative to the public rehabilitation of the whole irrigation system. Of course, this is not a generalizable solution, but it can be useful in specific cases. Regarding WUA cost recovery, problems arise when the WUA General Assembly approves lower ISFs than recommended by the management, when - as in the case of Jordan-WUAs are not entitled to recover water fees from farmers, when tariff setting is not transparent or when the ISF collection system is not adequate. The final point in WUA cost recovery is the economic profit from irrigated farming. When farmers 
make relevant benefits WUAs tend to operate satisfactorily. Therefore, securing farmers' wellbeing is a way to ensure irrigation system maintenance and smooth operation. Unfortunately, the economic result of irrigated farming is the responsibility of the Ministry of Agriculture, while PIM/IMT is the responsibility of the IA. Coordination of efforts between these two institutions is infrequent.

\section{Current Solutions}

The following sections present eight solutions to the abovementioned problems of water governance in irrigated areas. These solutions that been proposed, described, and/or experimented in different contexts. Table 3 presents a classification of the contribution of the identified solutions to the problems. Each solution addresses several problems with different degrees of contribution. In the following description of each problem, two paragraphs are also used: a description according to the scientific literature (readers should note that there is much less literature on solutions than there is on problems), and the professional experience of the authors of this paper. The order in which solutions are presented is loosely based on the order in which the related problems were described.

\subsection{High-Level Political Commitment}

One of the causes for the early case of IMT in Mexico was the high-level political commitment [8]. This was very important in redefining the role of the IA after IMT, and in fostering cooperation between all actors. Garcés-Restrepo et al. [7] in their assessment of worldwide IMT efforts, identified high-level political commitment as a key recommendation for on-going programs. According to these authors, commitment needs to be strong at the highest possible level for a sustained period. They recommended study tours to irrigation systems with successful reform applications to encourage political support.

The authors agree on the importance of political commitment, and on the need for commitment at the highest political level. However, experience indicates that this is very difficult to obtain and sustain. Therefore, reforms are commonly performed under partial commitment conditions.

\subsection{Additional Legal Reforms Concerning the WUAs and the Agency}

The relation between the Agency and the WUAs is guided by the principle of subsidiarity: decisions are made at the lowest possible level [7]. The application of PIM/IMT has led to a reorganization of the Agency focusing on decentralization and downsizing. This implies withdrawing from the downstream-end levels of the irrigation network (Figure 1), focusing on WUA capacity-building, regulating the irrigation sector, river hydrology, canal management, and developing monitoring and evaluation capacities [7]. On the side of the WUAs, reform must ensure that the WUA roles are clear and sufficient [4], and that farmers enter PIM processes with sufficient clarity and well-defined responsibilities [32]. These changes must be framed in a supportive policy, regulatory and legal environment [16], which needs to address all aspects of irrigation governance: financial transparency, equity in water allocation [4], dispute resolution [15], collective decision-making, equity in cost allocation, and a mutually beneficial relation with the agency [32]. The establishment of WUAs requires clarifying responsibilities with parallel rural organizations, such as cooperatives or villages [23]. These reforms must be complemented by specific provisions to achieve financial self-sufficiency through planning and effective cost recovery [15]. In some cases reforms also include the establishment of tradable water rights [8]. In recent years, the need to reform the irrigation bureaucracies as part of IMT processes has gained importance [18]. This issue transcends irrigation governance, to address the way donors and government agencies approach development assistance. 
Table 3. Semi-quantitative contribution of the identified solutions to the problems identified in this paper. Contribution has been evaluated by the authors in a scale from 0 to 5, with 5 expressing the highest contribution. The table also presents the Difficulty of the Problems and the Power of the Solutions.

\begin{tabular}{|c|c|c|c|c|c|c|c|c|c|c|}
\hline & & \multicolumn{8}{|c|}{ Solutions } & \multirow[b]{2}{*}{$\begin{array}{l}\text { Difficulty of the } \\
\text { Problem, DP }\end{array}$} \\
\hline & & $\begin{array}{c}\text { High-Level } \\
\text { Political } \\
\text { Commitment }\end{array}$ & $\begin{array}{l}\text { Additional Legal } \\
\text { Reforms Concerning the } \\
\text { WUAs and the Agency }\end{array}$ & $\begin{array}{c}\text { Flexible, } \\
\text { Adaptive Reform } \\
\text { Programs }\end{array}$ & $\begin{array}{l}\text { Rehabilitation/ } \\
\text { Modernization } \\
\text { Programs }\end{array}$ & $\begin{array}{c}\text { Capacity-Building } \\
\text { (WUAs, Agency and } \\
\text { Government Officials) }\end{array}$ & $\begin{array}{l}\text { Monitoring and } \\
\text { Evaluation at the } \\
\text { WUAs }\end{array}$ & $\begin{array}{l}\text { External } \\
\text { Support }\end{array}$ & $\begin{array}{l}\text { Benefit from } \\
\text { Farming and } \\
\text { Participation }\end{array}$ & \\
\hline \multirow{9}{*}{ Problems } & $\begin{array}{l}\text { Agency and government } \\
\text { officials resist reform }\end{array}$ & 5 & 3 & 3 & 1 & 2 & 2 & 1 & 1 & 2.8 \\
\hline & Farmers resist reform & 2 & 2 & 3 & 5 & 2 & 2 & 2 & 3 & 2.4 \\
\hline & $\begin{array}{l}\text { Weak legal and financial } \\
\text { reform framework }\end{array}$ & 5 & 5 & 3 & 1 & 1 & 1 & 1 & 2 & 2.6 \\
\hline & $\begin{array}{c}\text { Poor conception of the } \\
\text { construction/rehabilitation } \\
\text { projects of the irrigation system }\end{array}$ & 1 & 1 & 1 & 3 & 2 & 4 & 3 & 2 & 2.9 \\
\hline & Irrigation systems deteriorated & 3 & 3 & 2 & 5 & 3 & 3 & 3 & 4 & 1.8 \\
\hline & $\begin{array}{c}\text { Unsuitable WUA } \\
\text { organization structure }\end{array}$ & 2 & 5 & 3 & 1 & 2 & 2 & 3 & 3 & 2.4 \\
\hline & $\begin{array}{l}\text { Weak capacities of WUAs } \\
\text { (technical, managerial) }\end{array}$ & 1 & 1 & 2 & 2 & 5 & 4 & 4 & 4 & 2.1 \\
\hline & Inadequate WUA cost recovery & 1 & 3 & 3 & 2 & 2 & 5 & 3 & 5 & 2.0 \\
\hline & ower of the Solution, PS & 2.5 & 2.9 & 2.5 & 2.5 & 2.4 & 2.9 & 2.5 & 3.0 & \\
\hline
\end{tabular}


Reforms must explicitly declare WUA or farmer water rights and establish a clear WUA legal profile (public, private or public-private). The legal scope of WUA activities must also be addressed, specifying if activities other than water management are allowed for WUAs. On the other hand, as water governance becomes more hydrologic, explicit, and participative, it is important that WUAs are represented at the River Basin Organizations in charge of water allocation, emergency response and environmental management. To do so, WUAs need to be structured in associations or federations representing their interests at higher organizational levels. It is equally important that the technical bodies of the WUAs engage in communities of practice at the basin or national levels. This will ensure the propagation of good practices and innovations in water management. The transition of low-level water management from the Agency to the WUAs does not automatically generate the required authority at the WUAs to address conflicts in water management and to ensure ISF recovery. Legal reforms must address this problematic issue to prevent WUA discredit.

\subsection{Flexible, Adaptive Reform Programmes}

Effective collective arrangements are one of the keys to success in the self-governance of irrigation systems [16]. Garcés-Restrepo et al. [7] introduced the need for flexible and adaptive reforms, claiming for effective awareness campaigns and stakeholder consultations. Local boundaries need to be found for the responsibilities of both the Agency and the WUA, which need to complement each other in the new institutional arrangements [18]. Although the PIM/IMT model is well-established, Veldwisch and Mollinga [17] reported that its application in different areas of the world led to very different results. These authors addressed the term "institutional bricolage", coined by Sehring [36] as the "partly purposeful and partly unintentional process of the combination and transformation of institutional elements that results in a qualitatively new type of institution". The need for participation of WUAs in reform processes is firmly established today. However, the relative importance of the public, collective or private actors in irrigation system ownership and management is currently open to discussion. Meinzen-Dick [10] opted for a polycentric combination of each type of institutions after taking into consideration the strengths of the local institutions and after evaluating the possible synergies. The success of the early Mexican IMT case has been partially explained by its flexibility and adaptation to the local scene [8].

The main limitation to the application of this solution is the time required to assess the nature and characteristics of the local institutions, to consult the stakeholders and to arrive to conclusions about the institutional, technical, and financial aspects of the required reform. The requirements of the donor institutions and/or the local governments often put pressure on this phase of the process, resulting in incomplete assessments and fragile agreements with local stakeholders.

\subsection{Rehabilitation/Modernization Programmes}

According to Orstrom [26], users need to participate in the design of an infrastructure producing localized benefits, Conversely, they also have to contribute with their own resources, so that the public decision on investment should only be taken if users contribute both to the project design and funding. There is a general agreement on the need for rehabilitation/modernization, as related to the reform process. However, there have been different experiences on the relative timing of the reform and the rehabilitation/modernization. Kloezen et al. [8] reported how, in the successful Mexican IMT case, farmers believed that rehabilitation/modernization should have been performed prior to transference. However, the Agency did not engage in construction projects before transfer. Shortly afterwards, WUAs bought heavy construction machinery using ISFs. Farmers often express fear that IMT will imply full WUA responsibility and financial liability for rehabilitation/modernization. The commitment of the Agency to get technically and financially involved in these projects after IMT has facilitated the transfer process [5]. In Turkey, for instance, modernization/rehabilitation projects in transferred WUAs are assessed, guided and funded by the Agency (DSI) [37]. Incremental infrastructure improvement has been advocated as a continuous process of rehabilitation/modernization, opposed 
to the complete reconstruction of the irrigation system following a few decades of operation [5]. At the on-farm level, traditional surface irrigation systems have been replaced in some projects by sprinkler and drip irrigation systems, following high expectations on the applicability of these new systems [38]. The recent recognition of irrigation management as a key factor in improving irrigation performance has often reduced attention on the importance of updating the irrigation structures [39]. In fact, the combination of management and structural improvements constitutes a complete rehabilitation/modernization project.

The experience of the authors indicates that rehabilitation/modernization projects in developing regions often focus on the construction aspects and fail to explore the relation of the infrastructure with the natural resources and the farming systems. A wide margin for improvement exists in the adaptation of construction projects to local conditions. Aspects such as hydraulics and structural analysis receive much more attention than agricultural systems, on-farm irrigation systems, drainage, salinity, irrigation organization and operation and management.

\subsection{Capacity-Building (WUAs, Agency and Government Officials)}

Reform constitutes a new game in irrigation management, for which none of the actors have the required capacities. The change in the roles of the government officials, the Agency and the WUAs requires new capacities. Moreover, at the onset of reform, the public sector does not have the capacities required to train the WUAs [7]. The largest deficit in training appears at the WUAs, which need to build technical, financial, administrative, extension, agribusiness and marketing capacities ex-novo and in a short time $[7,24]$. A common solution is to organize training from the public sector for the leaders and the personnel of some of the new WUAs. In some cases, capacity-building programs have been extended to farmers.

Public budgets for capacity-building are always shorter than required. Infrastructure continues to find a more effective access to public funding than training does. Capacity-building programs have to beat the additional problem of focusing on small groups distributed throughout the complete irrigated area. Therefore, many projects resort to training trainers or WUA managers. An additional problem is that rural communities are not fit for standard training, and require long "on-the-job" capacity-building programs. Such programs could be developed in cooperation with nearby projects, promoting peer-to-peer, informal training. An evolution of the currently used capacity-building tools is required, since all actors seem to be dissatisfied with the current costs and results.

\subsection{Monitoring and Evaluation at the WUAs}

The importance of monitoring and evaluation in irrigated agriculture was first outlined in the 1980s with the aims of assessing the impact on the project beneficiaries (income, employment, quality of life) [40]. Vermillion and Sagardoy [5] structured the concept in the context of IMT. These authors issued a set of recommendations that - two decades later - continue to be critical for success. Among them, the importance of selecting a reduced number of information-efficient key indicators, the need to combine top- and bottom-directed monitoring, and the benefits of periodic reporting of monitoring and evaluation information to WUA governance bodies. Several monitoring and evaluation tools have been proposed in the last decades for irrigated areas, focusing on database technologies [41,42], remote sensing applications [43] and other information technologies.

An efficient, sufficiently funded monitoring and evaluation system should be able to provide real-time detection of the operational, financial and management problems of the WUA. The abundance of monitoring and evaluation tools for irrigated areas is in contrast with the low level of implementation of these procedures. In fact, examples of systematic monitoring and evaluation efforts in WUAs are not numerous, particularly in development contexts. 


\subsection{External Support}

External support is understood as personnel other than water users that contribute to perform the activities attributed to the WUA. These personnel can be hired by the WUA, can belong to an irrigation services company hired by the WUA or can belong to a firm participating in a PPP process. The importance of counting on sufficient ISF collection to hire WUA personnel was recognized by Orstrom [26], and later stated by Vermillion and Sagardoy [5]. These authors introduced the concept when describing IMT: farmers are not supposed to implement the service previously lent by the Agency. External services can cover a range of professional capacities, such as technical, legal, accounting, engineering, or communication. The goal of external support is to implement WUA policies. In the context of PPP, operation and management have been recognized as crucial tasks for external support [11].

WUAs established in developed regions have already gone a long way in securing external support. The last decade has seen the hiring of engineers (and other professionals) by WUAs to assist them during the process of rehabilitation and modernization. Later, these professionals have led the operation and management of modern infrastructure. In developing regions, the process is only incipient, and irrigation professionals are more frequent in the Public Administration than they are in the WUAs. The lack of professionals in the WUAs makes communication with the Government, the Agency, and service providers difficult. A key aspect in the hiring of professionals is the relation between the WUA budget and the cost of a professional. The minimum WUA size (in hectares) required to hire a professional changes with the local development level. The Federation of several local WUAs can help attain the minimum required WUA size.

\subsection{Benefit from Farming and Participation}

When analyzing the literature, the reform of irrigation systems is often perceived by authors as dissociated from the agricultural systems that these supply. Some authors have recognized the importance of linking irrigation and agriculture. For instance, when analyzing the sustainability of WUAs in Thailand, Ounvichit et al. [35] signaled that explicit economic returns from irrigated agriculture would have farmers participate in WUAs and to support their activities. Similar opinions were cast by Hamada and Samad [4] when listing the requisites for sustainable PIM processes: farmers must receive tangible benefits from using water. A similar principle was expressed by Ul Hassan [16] when addressing water users: the benefits of governance and management must exceed the cost.

While this is a common-sense principle, it can explain several experiences lived by the authors when analyzing irrigation projects in developing regions. Inactivity by farmers is often associated to non-profitable crops, governmental or non-governmental subsidies in the form of food or commodities, or completely deteriorated irrigation/drainage structures or soil fertility. Conversely, the existence of a profitable economic model - leading families beyond subsistence-often constitutes a sufficient incentive to establish a vigorous WUA. This issue is linked to the conception of the rehabilitation/modernization programs: the new WUA infrastructure needs to be designed for agricultural success in family farming, company farming or both. Unspecific irrigation system designs, not paying attention to the final purpose of irrigation water delivery (creating wealth through farming) are bound to meet relevant sustainability problems. WUAs can also contribute to farmers' benefits by promoting the creation of cooperatives, the cultivation of market-oriented crops and the establishment of companies providing irrigation services.

\section{A Case Study Approach to Problems and Solutions in Irrigation Governance}

Seven case studies are described in this section. These involve different types of WUAs and different degrees of success in performance and service to the farmers and to the public interest. The case studies are in seven countries located in four continents. Two of these countries are included in the list of Low-Income Developing Countries produced by the International Monetary Fund [44] 
(Cameroon and the Kyrgyz Republic). Three countries are included in the list of Emerging Market Economies (Chile, Georgia, and Jordan). Finally, two advanced economies are included (Portugal and Spain). Even in advanced economies, irrigation systems are deeply related to rural development. Therefore, the seven case studies provide insights of different rural development contexts and different types of reforms. In the following sections, case studies are presented in country alphabetical order. The name of the specific WUAs has been omitted.

\subsection{Cameroon}

The WUA makes part of an irrigated area supplied by a 35-year old canal with a capacity of $14 \mathrm{~m}^{3} / \mathrm{s}$. Water is abstracted from a reservoir essentially used for hydropower. The original project included irrigation in both riverbanks, covering eleven thousand hectares of public land. However, the currently irrigated area only extends to six hundred hectares. The project focuses on rice production, with family farms of about 0.5 ha. Water governance is complex, with several Ministries and public bodies implied in the project at different levels. Government officials do not have experience in planning or managing irrigated agriculture. An additional level of complexity is introduced by the ethnic profile of the farmers, which leads to different approaches to farming. Very few locals have capacities in irrigated agriculture. The project area has received intense migrations from Cameroon and from neighboring countries. This has exponentially increased the population of the local capital city in the last decade. The current population exceeds three hundred thousand inhabitants, which are exposed to relevant food security problems. This is the most problematic case study in this paper, with serious difficulties in the approach of the Agency and the Government, in the reform framework, infrastructure and in the capacities and organization of the WUA, which is far from recovering the operation and management costs. Discussions are currently being held with international funding agencies to identify the most adequate solutions to this complex case.

\subsection{Chile}

This WUA, located in the arid coastal north of Chile, is reasonably organized, and has relevant capacities to maintain and improve its irrigation infrastructure. It integrates mining companies (the largest water right holders in the area) in addition to farmers. The WUA organizational model is well developed, participative and offers guarantees to members, although its small size constitutes a relevant challenge. During the recent liberalization of water in Chile (1998-2005), perpetual water rights were assigned. These rights are not coupled to land tenure, leading to an active water market. Mining companies have recently bought water rights to profit from the high price of copper ore. Farmers selling water rights go out of business because local aridity requires irrigation for any agribusiness operation. In general, farmers have very good knowledge of their production system, and grow fruits and fresh produce for international markets. A few negative aspects can be highlighted. For instance, several legal and organizational aspects could be strengthened. The absence of an IA guiding and organizing local WUAs, and managing large hydrologic systems is resulting in poor coordination and poor hydrological planning. In an area where water rights exceed renewable water resources by far, this is a critical issue, one that could eventually lead to water bankruptcy.

\subsection{Georgia}

The case study makes part of a thirty thousand hectare irrigation system is managed by LLC Georgian Amelioration, a public agency acting as the IA. The irrigated area is currently experiencing a rehabilitation process. After decades of abandonment and migration to the nearby capital city, not much social capital remains: an aged society is in place, with little interest in irrigation. In fact, irrigation is currently performed in less than $10 \%$ of the system area. Past attempts to constitute WUAs have failed. LLC has a bureaucratic approach, characterized by slow administrative progress. There is a strong need for success of the WUA model, and complete remodeling of the public governance. The sustainability of the area is seriously threatened by the lack of a profitable agricultural model, 
compatible with the local social traits. This may be a typical case of Public Administration failure, leading to PIM/IMT. However, the process is not adequately grounded, and success seems very unlikely in the current circumstances. The combination of a bottom-up, credible project for local agricultural production and a concessional model for infrastructure development could reverse the current trends, accelerating the process and counting with local support.

\subsection{Jordan}

The cooperative performing the WUA role is in the Jordan Valley. It covers an irrigable area of 1026 ha, with 254 farm units frequently using localized irrigation. The cooperative is part of a government PIM/IMT program whereby several irrigation systems were transferred to farmers between 2001 and 2010. By 2012, 18 water cooperatives were established, covering some 20,000 ha ( $60 \%$ of the irrigated area of the country). The irrigation transfer process started with a technical report by Jordan Valley Authority (JVA, the IA) regarding the condition of the irrigation system to be transferred and following the training of leaders and staff. WUAs in Jordan are registered as independent financial and administrative cooperatives (under cooperative law and by laws) and are under the umbrella of the Jordan Cooperative Corporation (JCC). JCC provides a variety of supporting services: training in accounting matters, auditing, and some scattered monitoring. JVA intends to move WUAs under its oversight, but so far this has not taken place. Farmers in the JVA are mostly producers of fruit trees and vegetables, exporting to Europe and Gulf countries. Most of the farmers are middle to old age and have performed relevant investments in greenhouses and farm reservoirs. Lack of network rehabilitation and water scarcity limit farmers' satisfaction. The cooperative has promoted some training activities for the farmers that were widely appreciated. Fruitful cooperation exists between JVA and the cooperative. Neither the Cooperative nor its members have water rights, and this the general case in Jordan. Members pay very low fees to JVA, covering only a fraction of the actual operation and management costs. The cooperative is heavily subsidized by JVA, resulting in low independence. Less than $50 \%$ of the farmers covered by the irrigation network are members of the cooperative, since this is not mandatory to have access to water. The irrigation infrastructure is more than 60 years old, and maintenance is poor. The Government is aware of the unsustainable financial situation, but a strong increase of water fees would not be socially acceptable. Cooperatives are demoralized by their scarce level of autonomy. Unless urgent actions are taken, the survival of this system will remain linked to the continuity of the subsidies to the cooperatives.

\subsection{Kyrgyz Republic}

The WUA is in Fergana, in a traditional irrigation scheme characterized by large irrigation water supply and very small WUAs. The irrigation system was the target of a USAID project on WUA development. Therefore, farmers and the IA officers are aware of the theory and have moderate interest on the practice: farmers do not believe in the WUA model. Infrastructure maintenance is delayed by organizational problems, and by factors such as the lack of construction materials. The combination of poor water management and poor infrastructure maintenance results in poor water service. When this is combined with an aged farmer's community, the result is abandonment of irrigation practice and emigration to nearby cities. There is currently no perspective for a modern, profitable farming system based on irrigation. Under these conditions, the sustainability of the area is seriously threatened. The Government could eventually attract an international donor for irrigation rehabilitation / modernization and PIM/IMT. The abundance of irrigation water brings no guarantee to the sustainability of the irrigation system. Local change should start by the farming systems and the institutional arrangements for water management.

\subsection{Portugal}

The irrigation system involves a hundred and ten thousand hectares of new irrigated land in the Alentejo region. The main canal supplies water to WUAs and large farms. The case study WUA 
involves farmers of all sizes. The project is managed by a public company, EDIA, acting as the IA. EDIA has well-trained directive and technical personnel, and performs design, tendering, supervision, and management of all infrastructure: from source to farm. The project is based on the irrigation of Mediterranean crops: $50 \%$ olive, $25 \%$ cereals, $25 \%$ horticulture. Under this project, WUAs were quickly formed and federated. In general, the case study WUA is a success story. Success is only partial, for there are a few partial negative aspects, related to the WUA organization structure and capacities. Despite the public nature of EDIA, it effectively responds to users' needs, and promotes efficiency in water management and profitability in farming.

\subsection{Spain}

The case study WUA is in a PPP irrigation development in the north of the country. The large presence in Spain of multinational urban water utility companies and the control of national debt by the European Union have facilitated the development of this model in Spain. In fact, two PPP irrigation projects are on-going, exceeding fifty thousand hectares each. In both cases, the PPP is developing new irrigated land. These two projects show large organizational differences. One of the key positive aspects of these projects is that the WUA remains in the hands of farmers, as required by the Spanish water law. The technical bodies of the WUA and the IA are provided by the company (or group of companies) running the PPP for the local authorities. These companies build and operate the project under a concessional model, similar to well-known examples (highways). On the negative side, the PPP model can generate large costs that the public system and/or the farmers cannot afford. In fact, companies carry more overheads and taxes, as compared to direct action by public authorities. The expansion of the PPP model is limited by the low cost of WUA management operations, since WUAs benefit from their deep knowledge of the local environment and from their non-profit nature. Political interference can always be a key negative factor in irrigation PPPs. The two on-going projects in Spain show relevant differences in economic and managerial performance. In the long run, convergence between irrigation and urban water seems to be the goal for multinational water utility corporations. This perspective could count on the support of some political leaders.

\section{From Problems to Solutions: A Semi-Quantitative Approach}

A semi-quantitative approach was developed to assess the potential contribution of each solution to the documented problems (Table 3). Quantitative marks were used for this purpose, ranging from 0 to 5 (where 0 implies that a particular solution does not contribute to the solution of a problem, and 5 implies that the solution is very relevant to this problem). Table 3 constitutes the problem-solution, or $M$ matrix. The numerical values of the coefficients of $M$ presented in Table 3 are not aimed to be universal. They correspond to the appreciation of the authors, and we believe that different persons would end up with different coefficients. The same can be said of the region of the world where the matrix is to be applied: different matrices would probably apply to different regions. The application of the proposed semi-quantitative approach to an irrigated area should start with the stakeholders' discussion of the matrix coefficients in the local context.

Table 3 presents two additional indicators:

$$
\begin{gathered}
\text { Difficulty of the Problem : } D P_{i}=5-\frac{\sum_{j} M_{i j}}{n s} \\
\text { Power of the Solution : } P S_{j}=\frac{\sum_{i} M_{i j}}{n p}
\end{gathered}
$$

where $i$ is the sub index for problems, $j$ is the sub index for solutions, and $n p$ and $n s$ are the number of problems and solutions respectively. In this case, $n p=n s=8 . D P_{i}$ and $P S_{j}$ can range between 0 and 5 .

According to Table 3, the most difficult problems were: the poor conception of the construction/rehabilitation projects of the irrigation system, and the resistance to reform by the 
Agency and Government officials. The reason for this classification is that a few solutions can address these problems with moderate or high contributions. Conversely, the most powerful solutions were: farmers benefiting from participation and farming, additional reforms, and monitoring and evaluation. These solutions intensely contribute to a wide number of problems. The authors did not assign a value of zero to any matrix element. They considered that each of the identified solutions could have a positive influence of each problem, even if this influence was very small.

The next step is to assess the Intensity of the Problems of a given WUA using a scale of integer numbers also ranging from 0 to 5 , where 0 indicates that the problem has the lowest local importance, and 5 indicates maximum local importance. These scores constitute the problem vector $(P)$ :

$$
P=\left(p_{1}, p_{2}, p_{3}, p_{4}, p_{5}, p_{6}, p_{7}, p_{8}\right)
$$

Table 4 presents the elements of the problem vectors for the case study WUAs. For convenience, problem vectors are presented for each WUA as table columns. Again, the authors attributed non-zero values to each problem of the case study WUAs. The intensity of the problems in each area can be estimated by adding the elements of the problem vectors. Case study areas in Cameroon, Georgia, Kyrgyz Republic, and Jordan (in this order), ranked high in the list. On the other hand, case study areas in the most developed countries (Chile, Spain, and Portugal) presented relatively low problems. The most intense problems in the study case areas were the unsuitable organization structure and the capacities of the WUAs.

Table 4. Intensity of the problems in each of the case study WUAs. Problems were assessed by the authors in a scale from 0 to 5 , with 5 expressing the highest problem intensity.

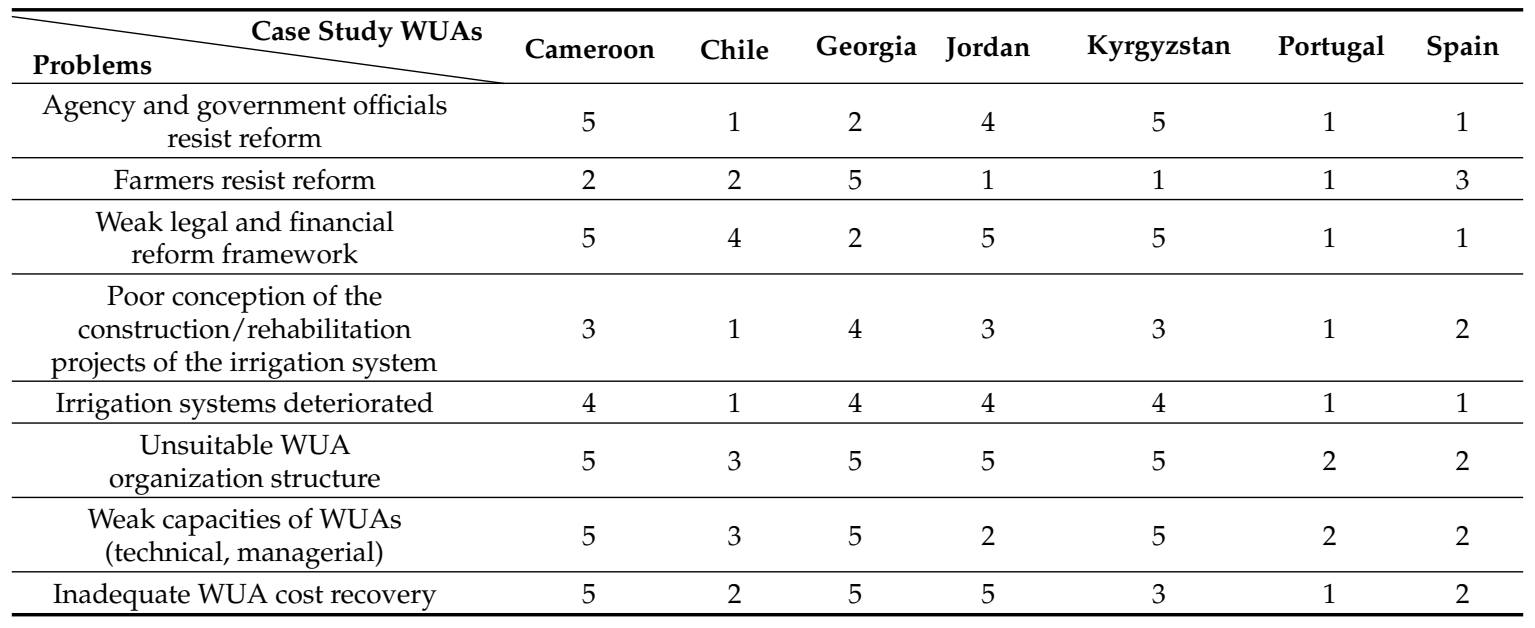

The pre-solution vector $\left(S^{\prime}\right)$ can be obtained as:

$$
S^{\prime}=P \times M
$$

where operator * is matrix multiplication. The pre-solution vector can be expressed as:

$$
S^{\prime}=\left(s_{1}^{\prime}, s^{\prime}{ }_{2}, s^{\prime}{ }_{3}, s^{\prime}{ }_{4}, s^{\prime}{ }_{5}, s^{\prime}{ }_{6}, s^{\prime}{ }_{7}, s^{\prime}{ }_{8}\right)
$$

Elements of the pre-solution vector represent the contribution of the solutions to the problems of each case study WUA. Elements take integer numbers ranging between 0 and $8 \times 5^{2}$. The solution vector $(S)$ is obtained by standardizing $S^{\prime}$ so that its elements are real numbers ranging from $\min _{i}\left(p_{i}\right)$ to $\max _{i}\left(p_{i}\right)$. This ensures that for a given case study area the elements of the solution vector use the 
same range of values as the problem vector. Following this approach, element $j$ of the solution vector can be obtained as:

$$
s_{j}=\min _{i}\left(p_{i}\right)+\frac{\left(s^{\prime}-\min _{j}\left(s_{j}^{\prime}\right)\right)}{\left(\max _{j}\left(s_{j}^{\prime}\right)-\min _{j}\left(s_{j}^{\prime}\right)\right)}\left(\max _{i}\left(p_{i}\right)-\min _{i}\left(p_{i}\right)\right)
$$

The higher the value of $s_{j}$, the more this solution can contribute to address the problems of the case study WUA.

The results of the application of the semi-quantitative approach to the case study WUAs are presented in Table 5. For convenience, solution vectors are presented for each WUA as table columns. Because of the procedure described in Equation (6), the intensity of the solutions in each area follows the same order as the problems. The most intensely recommended solutions were: users benefiting from farming and participation, additional reforms concerning the WUA and the Agency, and Monitoring and Evaluation of the WUAs.

Table 5. Contribution of the solutions to the problems of each case study WUA, as estimated using the proposed semi-quantitative approach. Contributions are expressed in a scale from 0 to 5 , with 5 expressing the highest contribution intensity.

\begin{tabular}{|c|c|c|c|c|c|c|c|}
\hline $\begin{array}{ll}\text { Solutions } & \text { Case Study WUAs } \\
\end{array}$ & Cameroon & Chile & Georgia & Jordan & Kyrgyzstan & Portugal & Spain \\
\hline High-level political commitment & 4 & 2 & 2 & 3 & 4 & 1 & 1 \\
\hline Flexible, adaptive reform programs & 3 & 2 & 3 & 3 & 3 & 1 & 2 \\
\hline Rehabilitation/modernization programs & 2 & 1 & 4 & 1 & 1 & 1 & 2 \\
\hline Monitoring and Evaluation at the WUAs & 4 & 2 & 5 & 3 & 4 & 2 & 3 \\
\hline External support & 3 & 2 & 4 & 2 & 3 & 2 & 2 \\
\hline Benefit from farming and participation & 5 & 4 & 5 & 4 & 4 & 2 & 3 \\
\hline
\end{tabular}

A detailed discussion of the solutions is presented for the case study in Jordan, which is in the middle of the ranking list for the intensity of its problems. According to the proposed methodology, the solution contributing most to the identified problems is to perform additional reforms in the WUAs and the Agency. Additional reforms should address the cooperative nature of the users association, the close relation to the JVA, and the low-cost recovery. A new legislative framework is required to create a specific WUA legal entity, to separate the WUA from the Agency, and to attain WUA financial security. The next identified solution by intensity is to increase the benefit of water users from farming and participation. While farmers export most of their products, participation in the cooperative is not sufficiently beneficial for them (only half of the farmers participate and pay fees). The next priorities include political commitment, flexible, adaptive reforms, and monitoring and evaluation. Solutions to the Jordan case study did not prioritize rehabilitation and modernization, capacity-building or external support.

The proposed methodology has provided insight on the governance problems and solutions of the seven case study areas. However, shortcomings can be expected when it is applied to specific areas. A key shortcoming is related to the relative timing of the problems and the solutions. Discussions among the authors of this paper evidenced that the contribution of the solutions to the problems depends on when problems appear, and solutions are planned in a given irrigation system. For instance, we attributed a contribution of 3 points to rehabilitation/modernization programs when addressing the problem of poor conception of the construction/rehabilitation projects. If this problem was detected during the first years of project implementation, rehabilitation/modernization could 
have a small contribution. If-on the contrary-at the time of the analysis the poorly conceived project had been in operation for decades, the contribution of rehabilitation/modernization would be at the maximum level. Consequently, results would be more accurate if the exercise was applied to WUAs sharing the same timing of problems and solutions. The problems with the timing of problems and solutions can be illustrated by the case study in Spain, where the solution "rehabilitation/modernization programs" obtained 2 points. This is a low mark, but the solution makes no sense in a system largely under construction. This solution received the same mark as other, clearly more suited solutions, such as capacity-building of the WUAs or flexible and adaptive PPP processes.

Finally, the results of the proposed semi-quantitative approach need to be carefully interpreted and screened for unexpected results, which can appear in all proposed solutions. This methodology must be seen as a source of insight and a way to integrate and structure stakeholders' discussions. In fact, a participative approach should be used to elaborate the problem-solution matrix and the problem vectors, as well as to discuss and interpret the solution vectors. The assessment of the solutions for each case study area can be used as a starting point to discuss the prioritization of public reforms and WUA developments.

\section{Conclusions}

The critical review the problems and reported solutions in the governance of irrigated areas in developing countries permitted elaboration of a list of eight problems and eight solutions. The elements of the list were produced from the evidence in the literature and the experience of the authors. Dozens of scientific and technical papers were analyzed from the 1980s onwards, and their conclusions were analyzed from the scientific, technological, managerial, and engineering experience of the authors. We recognize that a different set of authors could have produced a different structure of problems and solutions. However, we believe that the elements of our lists would constitute the pillars of the findings of different authors.

We have presented a semi-quantitative approach to relate solutions to problems in a case study context. Seven case study WUAs were analyzed from seven countries in four continents. The approach is based on the calculation of a solution vector for each case study area by multiplying a problem vector with a problem-solution matrix. The method rests upon the quantification of problems, solutions, and their interactions using a $0-5$-point scale.

Our analysis has shown the usefulness of this concept, which seems particularly adequate in the context of stakeholders' discussions. The solution vectors provide insight on the adequacy of policy, infrastructure and organizational solutions contributing to improved irrigation governance. A local fine-tuning of the coefficients defining the problem vector and the problem-solution matrix seems required to draw conclusions effectively guiding decision-making. The approach seems particularly suited for WUAs having similar timing between the identified problems and solutions. Finally, variability in the problems of the analyzed WUAs is required to obtain variability in the solutions, facilitating policy development or prioritization.

Author Contributions: Enrique Playán, Juan Antonio Sagardoy and Rosendo Castillo contributed to all efforts leading to the production of this paper.

Funding: This research received no external funding.

Conflicts of Interest: The authors declare no conflict of interest.

\section{References}

1. Suhardiman, D.; Giordano, M. Is there an alternative for irrigation reform? World Dev. 2014, 57, 91-100. [CrossRef]

2. AQUASTAT. Area Equiped for Irrigation; Prepared by AQUASTAT, FAO's Global Information System; Food and Agriculture Organization of the United Nations: Roma, Italy, 2014. 
3. AQUASTAT. Irrigated Crops; Prepared by AQUASTAT, FAO's Global Information System; Food and Agriculture Organization of the United Nations: Roma, Italy, 2014.

4. Hamada, H.; Samad, M. Basic principles for sustainable participatory irrigation management. JARQ Jpn. Agric. Res. Q. 2011, 45, 371-376. [CrossRef]

5. Vermillion, D.L.; Sagardoy, J.A. Transfer of Irrigation Management Services; Food and Agricuture Organization of the United Nations: Rome, Italy, 1999; p. 99.

6. Poddar, R.; Qureshi, M.E.; Syme, G. Comparing irrigation management reforms in Australia and India-A special reference to participatory irrigation management. Irrig. Drain. 2011, 60, 139-150. [CrossRef]

7. Garcés-Restrepo, C.; Vermillion, D.L.; Muñoz, G. Irrigation Management Transfer: Worldwide Efforts and Results; Food and Agriculture Organization of the United Nations: Rome, Italy, 2007; p. 63.

8. Kloezen, W.H.; Garcés-Restrepo, C.; Johnson, S.H. Impact Assessment of Irrigation Management Transfer in the Alto Rio Lerma Irrigation District, Mexico; International Irrigation Management Institute: Colombo, Sri Lanka, 1997; p. 34.

9. Rosegrant, M.W.; Binswanger, H.P. Markets in tradable water rights-Potential for efficiency gains in developing-country water-resource allocation. World Dev. 1994, 22, 1613-1625. [CrossRef]

10. Meinzen-Dick, R. Beyond panaceas in water institutions. Proc. Natl. Acad. Sci. USA 2007, 104, 15200-15205. [CrossRef] [PubMed]

11. Prefol, B.; Tardieu, H.; Vidal, A.; Fernandez, S.; Plantey, J.; Darghouth, S. Public-private partnership in irrigation and drainage: Need for a professional third party between farmers and government. Irrig. Drain. 2006, 55, 253-263. [CrossRef]

12. Trier, R. Review of international experience with public-private partnership in the irrigation subsector. Irrig. Drain. 2014, 63, 212-220. [CrossRef]

13. Yildirim, Y.E.; Cakmak, B. Participatory irrigation management in turkey. Int. J. Water Resour. Dev. 2004, 20, 219-228. [CrossRef]

14. Teamsuwan, V.; Satoh, M. Comparative analysis of management of three water users' organizations: Successful cases in the Chao Phraya delta, Thailand. Paddy Water Environ. 2009, 7, 227-237. [CrossRef]

15. Bhatt, S. How does participatory irrigation management work? A study of selected water users' associations in Anand district of Gujarat, Western India. Water Policy 2013, 15, 223-242. [CrossRef]

16. Ul Hassan, M.M. Analyzing governance reforms in irrigation: Central, south and West Asian experience. Irrig. Drain. 2011, 60, 151-162. [CrossRef]

17. Veldwisch, G.J.A.; Mollinga, P.P. Lost in transition? The introduction of water users associations in Uzbekistan. Water Int. 2013, 38, 758-773. [CrossRef]

18. Suhardiman, D. The power to resist: Irrigation management transfer in Indonesia. Water Altern. 2013, 6, $25-41$.

19. Senanayake, N.; Mukherji, A.; Giordano, M. Re-visiting what we know about irrigation management transfer: A review of the evidence. Agric. Water Manag. 2015, 149, 175-186. [CrossRef]

20. Renault, D.; Facon, T.; Wahaj, R. Modernizing Irrigation Management-The Masscote Approach: Mapping System and Services for Canal Operation Techniques; Food and Agriculture Organization of the United Nations: Rome, Italy, 2007; volume 63, p. 207.

21. Asthana, A.N. Is participatory water management effective? Evidence from Cambodia. Water Policy 2010, 12, 149-164. [CrossRef]

22. Meinzen-Dick, R.; Raju, K.V.; Gulati, A. What affects organization and collective action for managing resources? Evidence from canal irrigation systems in India. World Dev. 2002, 30, 649-666. [CrossRef]

23. Hu, X.J.; Xiong, Y.C.; Li, Y.J.; Wang, J.X.; Li, F.M.; Wang, H.Y.; Li, L.L. Integrated water resources management and water users' associations in the arid region of northwest china: A case study of farmers' perceptions. J. Environ. Manag. 2014, 145, 162-169. [CrossRef] [PubMed]

24. Yami, M. Sustaining participation in irrigation systems of Ethiopia: What have we learned about water user associations? Water Policy 2013, 15, 961-984. [CrossRef]

25. Aydogdu, M.H.; Yenigun, K.; Aydogdu, M. Factors affecting farmers' satisfaction from water users association in the Harran plain-gap region, turkey. J. Agric. Sci. Technol. 2015, 17, 1669-1684.

26. Orstrom, E. Crsfting Institutions for Self-Governing Irrigations Systems; Center for Self-Governance: San Francisco, CA, USA, 1992. 
27. Vos, J. Understanding water delivery performance in a large-scale irrigation system in Peru. Irrig. Drain. 2005, 54, 67-78. [CrossRef]

28. Cleaver, F.; Toner, A. The evolution of community water governance in Uchira, Tanzania: The implications for equality of access, sustainability and effectiveness. Nat. Resour. Forum 2006, 30, 207-218. [CrossRef]

29. Kiymaz, S. Problems and Solutions for Water User Associations in the Gediz Basin Example. Ph.D. Thesis, University of Çukurova, Çukurova, Turkey, 2006.

30. Caizhen, L. Gender issues in water user associations in china: A case study in Gansu province. Rural Sociol. 2008, 18, 150-160. [CrossRef]

31. Mahdhi, N.; Sghaier, M.; Smida, Z. Efficiency of the irrigation water user association in the Zeuss-Koutine region, South-Eastern Tunisia. New Medit 2014, 13, 47-55.

32. Omid, M.H.; Akbari, M.; Zarafshani, K.; Eskandari, G.H.; Fami, H.S. Factors influencing the success of water user associations in Iran: A case of moqan, tajan, and varamin. J. Agric. Sci. Technol. 2012, 14, 27-36.

33. Mekonnen, D.K.; Channa, H.; Ringler, C. The impact of water users' associations on the productivity of irrigated agriculture in Pakistani Punjab. Water Int. 2015, 40, 733-747. [CrossRef]

34. Johnson, S.H. Management Transfer in Mexico: A Strategy to Achieve Irrigation District Sustainability; Resarch Report 16; International Irrigation Management Institute: Colombo, Sri Lanka, 1997; p. 39.

35. Ounvichit, T.; Ishii, A.; Kono, S.; Thampratankul, K.; Satoh, M. An alternative approach to sustainable water users' organization in national irrigation systems: The case of the Khlong Thadi weir system, Southern Thailand. Irrig. Drain. 2008, 57, 23-39. [CrossRef]

36. Sehring, J. Path dependencies and institutional bricolage in post-soviet water governance. Water Altern. 2009, 2, 61-81.

37. Koc, C. Sustainability of irrigation schemes transferred in Turkey. Irrig. Drain. 2018, 67, 242-250. [CrossRef]

38. Postel, S.; Polak, P.; Gonzales, F.; Keller, J. Drip irrigation for small farmers-A new initiative to alleviate hunger and poverty. Water Int. 2001, 26, 3-13. [CrossRef]

39. Plusquellec, H. Is the daunting challenge of irrigation achievable? Irrig. Drain. 2002, 51, 185-198. [CrossRef]

40. Biswas, A.K. Monitoring and evaluation of irrigated agriculture-A case-study of Bhima project, India. Food Policy 1987, 12, 47-61. [CrossRef]

41. Mateos, L.; López-Cortijo, I.; Sagardoy, J.A. Simis: The fao decision support system for irrigation scheme management. Agric. Water Manag. 2002, 56, 193-206. [CrossRef]

42. Playán, E.; Cavero, J.; Mantero, I.; Salvador, R.; Lecina, S.; Faci, J.M.; Andrés, J.; Salvador, V.; Cardeña, G.; Ramón, S.; et al. A database program for enhancing irrigation district management in the Ebro valley (Spain). Agric. Water Manag. 2007, 87, 209-216. [CrossRef]

43. Ambast, S.K.; Keshari, A.K.; Gosain, A.K. Satellite remote sensing to support management of irrigation systems: Concepts and approaches. Irrig. Drain. 2002, 51, 25-39. [CrossRef]

44. International Monetary Fund. Seeking Sustainable Growth: Short-Term Recovery, Long-Term Challenges; International Monetary Fund: Washington, DC, USA, 2017. 